\title{
INTERJÚ EGY SHUAR UWISHIN-NEL
}

\author{
Lipták Noémi \\ Károli Gáspár Református Egyetem- Bölcsészettudományi Kar, \\ vallástudomány
}

\begin{abstract}
Absztrakt
Jelen tanulmány a shuar samanikus hagyomány kortárs gyakorlatát vizsgálja. A shuarok Ecuador délkeleti részén élnek az amazonasi esőerdőben. Tradíciójuk az ember és a transzcendens ősi kapcsolatát ôrzi. A shuar gyógyászatban a sámáni praktikák pontos ismerete és gyakorlása mellett kiemelt szerepet játszanak a Tanító Növények, mint a dohány és az ayahuasca. A növények tanítóként, orvosként élnek hitvilágukban, amiknek segítségével képes a gyógyító „másvilági” utazást tenni, ahol meglelheti a betegségek valódi okát. A letelepedett életmód, a globalizáció, a missziós tevékenységek, a pénz kikerülhetetlen megjelenése és az őserdő bányák általi kizsigerelése veszélyezteti a shuarok életét, nyelvét és hagyományát. Jelenkorunkban ez az átalakulás olyan sebességgel zajlik, hogy három egymást követő generációból, a középső korosztály elengedhetetlen közvetítővé vált. Értem ezalatt például, hogy az unokák csak spanyolul, a nagyszülők csak shuar-ul beszélnek így a középső generáció szó szerint is fordítóvá vált közöttük. Így a tradíció örökítése, életben tartása jelenti a sámán elsődleges feladatát napjainkban. Ez pedig a hagyomány és a bevett rituális gyakorlatok átalakulását eredményezi. A kutatás forrását, egy shuar nagycsaládnál végzett terepmunkám alatt gyüjtöttek (Morona Santiago, Ecuador, 2016) és egy sámánnal (uwishin) készített interjú jelenti, amit itt adok közre.
\end{abstract}

Kulcsszavak: shuar • sámánizmus • ayahuasca • tradíció

\begin{abstract}
The present study examines the traditions of contemporary Shuar shamanistic practices. The Shuars live in the South East part of the amazonian rainforest. Their tradition and customs preserve the ancient connection between Man and the Transcendent. In Shuar medicine besides the exact knowledge of shamanic practices and their usage there is an outstanding role of the „Healing Plants” such as tobacco and ayahuasca. In their belief system these plants live as healers with whose help the shamans are able to journey into another realm where the true source of ailments are revealed. Due to settled down, globalization, missionary work, the unavoidable presence of money and the increasing activity of the mining industry their tradition, language and lives are generally endangered. The speed of these changes are so fast that at present within 3 generations the middle one is inevitably becomes a mediator. This may mean that within a family the grandchildren only speak spanish and the grandparents only speak shuar therefore the middle generation literally becomes a mediator.

As a result the primary role of the shamans is to preserve and pass onto the tradition with its changes and necessary adaptions in customs and ritual practices. The source of my research was collected and based on the field work what I did at a Shuar family
\end{abstract}


(Morona Santiago, Equador 2016) and an interview with the shaman (Uwishin) that I will present in the following.

Keywords: shuar • shamanism • ayahuasca • tradition

\section{BEVEZETÉS}

Kutatásom fókuszában egy Ecuador területén élő shuar sámán nagycsalád napjainkban zajló életmódbeli és hiedelemrendszerét érintő változásai állnak. A folklorisztika egyéniségkutató módszerét alkalmazva kutatásom középpontjába a sámánt állítom, mint olyan személyt, aki a közösség hagyományainak autentikus és meghatározó képviselője (Ortutay szerk., 1977-1982). ${ }^{1}$ Az uwishinnel (sámánnal) utazásai során találkoztam és a jó viszonynak köszönhetően 2015-ben készítettem el a jelen interjút. Az interjú a sámán személyes történetein keresztül ad betekintést az amazonasi shuar törzs hitvilágába, rítusaiba. 2016-ban ennek az ismeretségnek köszönhetően meghívást kaptam az uwishintől, hogy látogassak el otthonukba, Shiram Yaa-ba, ahol a sámán nagycsalád él, Ecuador dél-keleti részén. A terepmunka alkalmával gyưjtött anyagok jelentik kutatásom elsődleges forrását.

\section{A SHUAR TÖRZS}

A jivaro indiánok törzsét négy altörzs alkotja: a shuar, az ashuar, az aguaruna és a huambisa. Az altörzsek Ecuador és Peru területén élnek az amazonasi őserdőben, négy külön nyelvjárást beszélnek (Rubenstein, 2002; Adelaar, 2004). A shuar név jelentése a föld embere, a kozmosz embere. A shuarok mind Peru, mind pedig Ecuador őserdeiben is jelen vannak. Kutatásom tárgya az Ecuador dél-keleti részén fekvő, Morona Santiago tartományban élő shuar sámán nagycsalád. Földjük megnevezése Shiram Yaa, ami szép csillagot jelent. Területükhöz Gualaquiza városa fekszik legközelebb.

A shuarok nagycsaládi egységekben élnek. A nagycsaládokban a felek vérségi, gazdasági és lokális kapcsolatban állnak egymással (Ortutay szerk., 19771982). A shuarok letelepedése csupán az elmúlt évtizedekben történt meg, előtte vándorló életmódot folytattak. A letelepedett életmód új helyzeteket, új kihívásokat jelent a létfenntartásban. Ezek közül a legfontosabb az állattartás és a növénytermesztés elsajátítása volt, valamint ezek elkerülhetetlen következménye, a pénz megjelenése. Mivel a letelepedett életmód korlátozza az élelem

Ortutay Gy. (Szerk.). (1977-1982). Magyar néprajzi lexikon. Budapest : Akadémiai Kiadó. 
mennyiségét és változatosságát is, a nagycsalád arra kényszerült, hogy bizonyos élelmiszereket a legközelebbi városban, Gualaquiza-ban vásároljanak meg. Ez az életmódváltás rendkívül gyors lefolyású volt. A napjainkban ötven év körüli korosztály volt az első, amelynek meg kellett tanulnia a pénz használatát. A náluk idősebb generáció még embert ölt, unokáik pedig már jól tájékozottak a Facebook világában is.

A nyelvhasználat változása ugyanilyen viharos sebességgel zajlott le a nagycsaládban. Az elmúlt évszázadban még mindenki a shuar nyelvet beszélte. Mára viszont már a spanyol a kommunikáció bevett nyelve. Ennek oka, hogy a 20. században a jezsuita rend újabb misszióba kezdett a Morona Santiago tartományban élő shuarok között. Az általam kutatott nagycsaládi egységben a legidősebb generáció csak a shuar nyelvet használja, az őket követő generáció mind a shuar-t, mind pedig a spanyolt, és a legfiatalabb generáció pedig már csak a spanyol nyelvet. Az a furcsa családon belüli helyzet alakult ki, hogy a nagyszülők unokáikkal csak a középső, „közvetíto” generáció segítségével tudnak kommunikálni.

Az elmúlt évek folyamán jó minőségü földutat építettek a közösség élőhelye és a város, azaz Shiram Yaa és Gualaquiza között, mely a városba jutás és az áram használat lehetősége miatt könnyebbé tette a shuarok életét. Ugyanakkor fontos tisztázni, hogy az utat nem a shuarok miatt építették, hanem a területükön folyó bányászat hozománya. Az őserdőben, a shuarok tulajdonában lévő területeken is, az őserdő más területeivel egyetemben napi 24 órában üzemelő arany és réz bányák vannak. A bányászatra az ecuadori kormány ad jogokat, jelen esetben kínai és amerikai befektetőknek. A shuar nagycsaládok közt e kérdés jelentős konfliktusokat generál napjaikban. Van, aki harccal venné fel a versenyt a bányák ellen és van, aki inkább egyességet kötne a befektetőkkel, hogy ha már területeiken bányászat folyik, részesedhessenek bizonyos juttatásokban. Azonban bárhogyan is nézzük a bányászat rombolja életfeltételeiket.

\section{HARCIAS IDENTITÁS}

Mint említettem, a shuarok a jivaro indiánok egyik altörzsét képezik. A 16. században erős összefogás jellemezte az altörzsek kapcsolatát. A jivarok évszázadok óta hírhedtek harcias identitásukról, a korabeli spanyol krónikák szerint 1599ben hatalmas mészárlást végeztek (Rubenstein, 2002). Megelégelve a környező városok közeledését az őserdőhöz és ennek következményeként területeik elvesztését, a jivarok huszonötezer spanyolt öltek meg egyetlen éjszaka leforgása alatt, két településen (Bitsch, 1968).

A jivarokat világhírúvé tette egyik harci hagyományuk, a tsantsa, a zsugorított fej. Pontos leírást találhatunk a tsantsa elkészítéséről és az utána következő rítusról például Bitsch (1968) tanulmányában. A harcos, miután levágta ellensége fejét, gyakorlott mozdulattal lehúzza a nyak hátsó részétől fogva a ko- 
ponyáról és az arcról a bőrt. Ezután egy emberi fej méretű kőre teríti a bőrt, majd hosszú főzés után egy narancsméretüre cseréli a követ, és a fejbőrt ismét főzni kezdi. A főzéstől a bőr tovább zsugorodik, miközben felveszi a kő formáját. Miután a bőr a megfelelő méretüre zsugorodott, a harcos müvészi módon növényi rostokkal összevarrja a fejen a szem, fül és a száj nyílását. Ezzel védi magát és a törzset az ellenség szellemétől, mivel a shuar hitvilágban a levágott fejben tovább él a megölt harcos szelleme. Az arc nyílásainak összevarrásával megakadályozzák, hogy a harcos szelleme árthasson. A tsantsa elkészítése egy rítussal zárul, aminek szándéka az ellenséges szellemek kiengesztelése és elűzése.

A jivaro férfiakat a csecsemőkortól kezdődő rituális beavatások és szertartások kivételes harcosokká nevelik a test és a szellem felkészítésével. Napjainkban már nem készítenek tsantsá-kat, azonban a harcos identitás ma is jelen van, átalakult formában. Ma harciasságuk nem fizikai módon értendő, hanem sokkal inkább szellemi, illetve a globalizáció, a pénz használattal kialakuló „új valósághoz" való alkalmazkodás küzdelmeként.

Életmódjuk megőrzött bizonyos autentikus vonásokat, a férfiak például vadászattal, házépítéssel és rituális tevékenységekkel járulnak hozzá a nagycsalád életéhez (Boglár, 2010). Az asszonyok szerepe ma is a növények gyưjtögetése, a maniókaszedés és elkészítése, a gyermeknevelés mellett (Rubenstein, 2002). Napjainkra ez kiegészült a rítusokon való részvétel lehetőségével, ami a modernizációs folyamatok következményeként jelent meg. A shuar törzs specifikuma, összehasonlítva más amazonasi közösségekkel, hogy a nők egyenrangú félként vehetnek részt a szertartások mindegyikén (Perruchon, 2003). Ezt példázza, hogy a férfiak beavatási rítusa, a vízesés szertatás (Natemamu), mára a nők számára is választható módját jelenti az Arutmmal (Nagy Szellem) való kapcsolatteremtésnek. Ennek következménye, hogy a törzs minden tagja egyéni tapasztalást szerezhet a tradícióról és így saját maga alakíthatja ki kommunikációs formáját, nyelvét Arutmmal. ${ }^{2}$ A samanikus kultúrákban a sámán kvalitása a szellemekkel való kapcsolatteremtés, kapcsolattartás, de a shuarok hagyományában ez minden egyén számára elérhető lehet.

Napjainkban már egy nyugati emberhez hasonlatos viseletben járnak, azonban a szertartásaik, rítusaik alkalmával magukra öltik tradicionális ruhájukat. Ez a nők esetében egy anyagból szabott kék ruhát jelent, amit rojtok és növényi magokból készült díszítő elemek színesítenek. A férfiak szakrális öltözete talpig érő szoknya, felső testüket meztelenül hagyva, és növényi magokból készült $x$ alakot formázó ékszerrel díszítve. Mindkét nem esetében a rituális öv használat a jellemző, ami védelmező funkciót tölt be. Ez készülhet szövetből, növényi magokból vagy tollakból. A férfiak tollakból készített fejdísze jelenti az öltözet koronáját, ami a shuar törzsnél a sárga, piros, kék és fekete színek kombinációjában pompázik.

\footnotetext{
A shuar törzs számára minden rítus alapvető célja az Arutammal való kapcsolatteremtés.
} 


\section{A SHUAR HITVILÁG ÉS GYÓGYÁSZAT}

Az Ecuador és Peru területére eső amazonasi őserdő bennszülötteinek hitvilága az ember és a transzcendens ősi kapcsolatát őrzi. A hiedelemvilág strukturált módjává a sámánizmus vált, aminek köszönhetően a rítusok és praktikák napjainkban is szakadatlanul fennálló tradícióként élnek.

Bonyolult hitvilágról van szó, megértéséhez a szakirodalom mellett empirikus terepkutatásra van szükség. A tanulmány elsődleges forrása az Ecuador amazonasi őserdeiben élő shuar törzsből származó sámánnal készített interjú, amit jelen cikkben adok közre. Az interjú betekintést ad a helyi sámánizmus gyakorlatába kiemelve a sámáni elhívás, a vízió, a Tanító Növények és a rítusok általi gyógyászat mozzanatait, melyról Luna is említést tesz (1984). ${ }^{3}$

A shuar samanikus hitvilág Nagy Szelleme (lat. supertranscendens, spanyolul Gran Espiritu), Arutam. A shuar sámánizmus terminusában a Szellem egy mindent körülvevő, a létezőkben permanensen élő szellemi jelenlét. Arutam, másképpen a Nagy Szellem olyan „tükörként” él hitvilágukban, amiben a létezők tükröződnek a megtestesülés különböző formáiban. Az Arutammal való kapcsolatteremtés és kapcsolatőrzés a legfontosabb szakrális tevékenysége a közösségnek, ami összes rítusuk alapját képezi. Hitvilágukban minden törzstagnak lehetősége van a kapcsolat megteremtésére Arutammal. Mivel a transzcendens és az ember kapcsolata személyes, ezért Arutamnak megtestesülései minden egyén számára más és más formában jelenhetnek meg.

A shuar nagycsalád számára Arutam legelső megnyilvánulása a vízesés, Tsunki, ahonnan a közösség eredezteti magát. A vízesés a szakrális helyszíne a beavatási rítusoknak, mint a sámán vagy a törzs fiainak felnőtté avatásának. (Gennep, 2007). Emellett a vízesés kapu is egyben a „másvilágba”, Arutam világába. Az ilyenfajta természeti képződmények szimbolikus kapu-szerepe a „másvilágba” gyakran megjelenik a samanikus kultúrák hitvilágaiban.

Példaként: a hagyomány szerint a sámánavatás alkalmával az idősebb sámán a vízesés mögé (vízfüggöny) vezeti a beavatandót. Ez a hely, mint mondják - a Nagy Apák, másképpen az ősök otthona, ahol a beavatandó kapcsolatba tud lépni Arutammal, illetve rátalálhat segítőszellemeire. A vízesés kultikus helye egy olyan komplex hitrendszer jelenlétét mutatja, amiben ok-okozati összefüggések és ismeretek hagyományos gyakorlatát figyelhetjük meg.

Az uwishin-i (sámáni) tudás eredetét a szellemi világból származtatják (Eliade, 2005). Az uwishin feladata a hagyomány gyakorlása, fenntartása, átadása, a szellemi világgal való folyamatos kommunikáció, valamint a gyógyítás. ${ }^{4}$ A gyógyítás eksztatikus állapotban zajlik, amit legfóképp a Tanító Növények fogyasztása tesz lehetővé. A shuar törzs nagybecsben tartott orvosa és orvossá-

\footnotetext{
Tanító növények kifejezést használ a közösség, azokra a növényekre vagy növényi főzetekre, amiknek orvosi, tanítói identitást tulajdonít hitviláguk.

$4 \quad$ A latin tradíció szó jelentése átadás.
} 
ga, azaz Tanító Növénye, az ayahuasca, nyelvükön Natem, ami egy két komponensből álló növényi főzet (Banisteriopsis caapiés Psychotria viridis; Bennett, 1992). A módosult tudatállapotban történő gyógyítás magyarázata, hogy a shuar hitvilágban a betegség mindig szellemi, lelki eredetü. Az eksztatikus állapotban lévő sámán képes meglátni a betegség, probléma valódi okát és kezelésének módját is, mivel a Natem (ayahuasca) betekintést ad számára a szellemi világba. Emellett a shuar nagycsalád gyógyászatának sajátossága, hogy az orvos (sámán) és betege is egyaránt fogyaszt a módosult tudatállapotot előidéző gyógyszerből (medicine, natem).

Az autentikus shuar orvoslás egyéni gyógyítást jelent, ami a sámán és betege közt zajlik. A shuar közösség három fő Tanító Növénnyel gyógyít az ayahuasca-val, a floripondio-val (angyaltrombita, lat. Brugmansia suaveolens) és a dohánnyal (lat. Nicotiana rustica). A dohány használata elengedhetetlen a shuar rítusok során. Egyrészt a dohány füstje távol tartja az ártó szellemeket a szertartástól (Bennett, 1992), másrészt hitviláguk szerint a Nagy Apa dohány lehetôvé teszi, hogy a rítus, gyógyítás kezdetén kifejezzék szándékukat (spanyolul propósito). Ez azért fontos, mert ebben a közösségben a szándék megfogalmazása képezi a rítusok alapját, hiszen ez az intenció vezeti és határozza meg a szertartás egészét. A gyakorlatban két módon fogyasztják a növényt, a dohánylevél vízben áztatott levét inhalálva, illetve kukoricacsuhéba tekert imadohányt elszívva. A shuarok egyik tagja sem dohányzik hétköznapi értelemben, kizárólag rituális céllal alkalmazzák a növényt.

Gyógyászatuk hagyományos gyakorlata a „rontó nyilak” eltávolítása. Ehhez tanítójuk, a Natem nyújthat betekintést a szellemi világba a sámánnak, hogy lássa a beteg körüli „rontó nyilakat”. Ezeket a nyilakat tsentsak-nak nevezik a shuarok. Hitrendszerükben a beteg lelki, szellemi nehézségei miatt elveszítheti az Arutam wakanit, a szellemi erőt. Emiatt az adott egyén ereje csökken, így könnyen rontó nyilak kerülhetnek testébe. A gyógyító feladata, hogy eksztatikus állapotban megtalálja ezeket a nyilakat, és eltávolítsa őket, azonban erre nem minden sámán képes. Ebből következik, hogy csak tapasztalt uwishin küldheti a tsentsak-at az ember testébe, amit fekete mágiának neveznek és szintén csak tapasztalt, idősebb uwishin képes ezeket eltávolítani. Ennek módja a kiszívásos sámáni praktika (Pellizzaro, 1978). ${ }^{5}$ A kiszívásos technika mellett gyakorolja az uwishin-i tradíció a befújás technikáját is. Ez általában a dohány levének hirtelen szájból történő befújását jelenti, a test bizonyos pontjaira. Általában a fájó testrészre, a két kéz tenyerébe és a fej búbjára. Ennél a technikánál is megjelenik a dohány tisztító funkciójának alkalmazása.

A shuar tradícióban a Natem rituális használata a gyógyítás mellett a felnőtté avatás, valamint a harc előtti közösségi rítus alapját is jelenti. Mára az auten-

Ennek gyakorlata, hogy a sámán a „megtalált” nyilat szájjal, szívásos technikával eltávolítja a beteg testéből, és gyógyító levegőt vagy dohánylevet fúj a helyére. 
tikus gyökereket őrző gyógyászat kiegészül közösségi gyógyászattal, ami az elmúlt évtizedek fejleménye (Turner, 2002).A sámán elsődleges feladatává napjainkban a hagyomány őrzése vált, a tradíció veszélyeztetetett helyzete miatt. A közösségi gyógyászattal nem összekeverendő a Natem fentebb említett közösségi rituális használata, vagyis a felnőtté avatás. A közösségi gyógyászat a sámán és betege közt zajló tradicionális gyógyításnak a ritualizált formája. A közösségi szertartáson az értendő, hogy a résztvevők minden tagja fogyaszt a növényi főzetből, azonban emiatt jól körül határolt rítusra van szükség ahhoz, hogy a gyógyulás folyamata felügyelt, szabályozott legyen.

\section{ÖSSZEFOGLALÁS}

Az amazonasi gyógyászati tradíciók az elmúlt két évtizedben bekerültek a globalizáció véráramába. E tradíciók életben tartását nem kizárólag a helyi őslakosok kultúrája tartja fenn, hanem a nyugati ember bizonyos szubkultúráiban megszülető igény is. A sámán már nem „csak” egy törzsi vezető, gyógyító, hanem mint orvos, lélekgyógyász, szakrális vezető végzi hivatását a munkájára igényt tartó közösségekben a világ minden pontján. Az uwishin interjújában megjelenik ez a küldetéstudat: „,az európaiaknak /.../ a rítusok és a növények segíthetnek abban, hogy felébresszék magukat hétköznapjaikból, ezáltal megláthatják saját világukat kívülről.” ${ }^{0}$ Megfigyelhető a Nyugat igénye ezekre a tudásokra, az emberekben rejlő szellemi erő újjáélesztésére, a természet közeli életmód újra formálására és egy tudatos spirituális fejlődésre. Robert J. Wallis (2003) például úgy véli, hogy az új pogány neo-sámánista mozgalmak ideje jött el napjainkban, ami nem pusztán rövid életű new-age divat, hanem a múlt felé forduló, a kulturális gyökereket kereső természettisztelő pogány kultuszok felélesztése.

Úgy gondolom azonban, hogy itt nem egy olyan kultusz felélesztéséről van szó, amit a nyugati emberek teremtenek maguknak, mivel ez a hagyomány még nem szakadt meg, hanem egy olyan szinkretizmusról, ami az amazonasi sámán munkájának funkcionális átalakulásán példázható. Az amazonasi sámánkultúra eredeti hazájából átszivárog a nyugati kultúrába, ahol újabb otthonára lelhet a tradíció, komoly transzformációkon átesve. A sámáni praktikák, illetve a rítusok menetének vizsgálatakor jelentős eltéréseket figyelhetünk meg. Aminek egyik fontos jellemzője, hogy a szertartások gyakorlata jóval strukturáltabb és szabályozottabb.

A tudományos világban is láthatunk az autentikus gyógymódok és hitrendszerek megismerésére való törekvéseket (Bokor, Frecska, Csányi \& Bry, 2012; Frecska, Móré, Vargha \& Luna, 2012). Az ayahuascával való gyógyászat lehe-

Lásd Interjú 
tősége számos kutatónak felkeltette az érdeklődését, mint például a magyar származású addiktológus Máté Gábornak. Mellette kiemelkedő kutatásokat végez Frecska Ede pszichiáter és farmakológus is, aki többek között az ayahuasca terápiás alkalmazásának lehetőségeit vizsgálja (Frecska, 2008; Frecska, Csokli, Nagy \& Kulcsar, 2004). A pszichedelikumokat pszichológiai úton közelíti meg Szummer Csaba (2011). Kutatásaival részben az ayahuasca-élmény pszichológiai, lélektani oldalát vizsgálja, beleértve a növényi főzet által megélt transzcendens-élményeket(2012a; 2012b). Másrészről pedig társadalomtudományi és filozófiai aspektusaiban is körültekintő kutatást végez eszmerendszerek és kulturális körülmények megfigyelésével (2015).

Összegzésként kijelenthetjük, hogy a shuar nagycsalád életében bekövetkezett átalakulások sajnálatos következménye, hogy a fiatal generáció távolodik kultúrájától, amit példáz a shuar nyelvtudás hiánya. Emellett megfigyelhető a másik szomorú változás, hogy a tradíció kis közösségekre korlátozódva él tovább. Az uwishin-nek reagálnia kell a törzs életében bekövetkezett változásokra, és ezt hivatásán keresztül teszi új módokat és formákat alkalmazva a hagyomány fenntartásának érdekében. Kutatásom alapján lehetségesnek tartom, hogy a globalizáció, a missziós tevékenységek és a letelepedett életmód hatása a hagyományra egy új sámáni funkciót eredményezhet. Így távlati szándékom, hogy a tradíció transzformáció okait és pontos menetét rögzítsem.

Spanyol nyelven készítettem interjúmat a shuar nagycsalád sámánjával, aminek magyarra fordított változata mélyebb betekintést adhat a shuar tradícióról és az uwishin-i hivatásról. 


\section{INTERJÚ A SHUAR UWISHINNEL \\ (Lipták Noémi, 2015, május 22, Budapest)}

\section{Mit jelent a shuar törzsnév?}

Shuar: ember, a föld embere, a kozmosz embere.

\section{Honnan eredeztetik magukat a shuarok?}

Két ismeretem van erről. Az egyik, hogy a shuarok a vízeséstől, Arutam első megnyilvánulásától eredeztetik magukat. A másik ismeretem pedig az, hogy a csillagokból érkeztek. Erre a shuar nyelv is utal. Az egyik a yāchicham, ami a csillagok nyelvét jelenti, a másik pedig a shuarchicham. Mivel a chicham a nyelv, a shuarchicham pedig az embernyelv.

\section{A Shuar nyelvet beszélik még?}

Minden idősebb ember beszéli a nyelvet, aki a közösségben él. Azonban nálunk most már lemenőben van a kultúra fontossága, mivel az életük fenntartásához a fiatalok már nem érzik szükségét a kultúra öröklésének. Ebben nagy szerepet játszik a nyugati, keresztény iskoláztatás megjelenése, ami kötelező számunkra hatéves kortól. Abban az esetben, ha szeretnénk, hogy az állam számon tartson minket, hogy kórházi ellátást kapjunk, azaz, hogy állampolgárok lehessünk.

\section{Shuar nyelven hogyan hívják a gyógyítót, sámánt?Uwishin.}

\section{Hol található a közösség kultikus helye?}

A vízesés a szent helyünk, mivel közösségünket (comunidad) Arutam-tól eredeztetjük, akinek ez a legelső megnyilvánulása a sok másik közül. Ez Shiram Yaa-i területünktől több óra sétával közelíthető meg.

\section{Mit tudhatunk Arutam-ról?}

Arutam az összes emberfeletti erő, ami körülvesz minket (lat. superstranscendens). Minden élőnek energiát ad, ami létezik a világon. Megszemélyesítődik a növényekben, az emberekben, a Holdban, a fényben, a Napban, a vízen keresztül, a tigrisben, a sasban, az anakondában. Bármiben meg tud jelenni, emiatt nagyon sok története van. Az összes olyan, mint a tigrismítosz, az anakondamítosz, illetve a sasmítosz. Mindenki, aki megtalálta Arutammal a kapcsolatot, kialakít egy saját, személyes nyelvet, amiben számára jelenik meg, és amelyen kommunikálni tud vele. A shuarok számára a két legfontosabb megtestesülés a vízesés, Tsunki és a Lungui, azaz Anyaföld. Említendő még az Arutamsakaim, az a Szellem, aki vigyázza a természetet, a fákat, az állatokat. Nase a szél, Ajompoum a tűz, Etcza a Nap, Nanto a Hold és Ya a csillagok Szelleme. 


\section{Mit jelent a saját Arutammal való megismerkedés, találkozás?}

Erre is kétféle forma van. Az egyik az egyenes vonal, ami vérszerinti levezetést jelent. A családi kapcsolatokban őrződik a hagyomány, azaz a dalok, a rítusok a szertartások, a vízesésszertartás, a dohány, a növények ismerete és a különböző gyógyító Tanító Növények használata. A böjtök pontos ismerete. A másik forma a rituális átadás. Amikor a sámán a rítusokon keresztül adja át a hagyományt. Az uwishini tradíció, azaz a sámáni tradíció ezeknek a praktikáknak a gyakorlását jelenti egy egész életen át.

\section{Mi a shuar hagyomány az Arutammal való kapcsolódáshoz?}

Ez egy köztes állapot élet és a halál közt. Nálunk a hagyomány e kapcsolat létrehozására a vízesés szertartás, illetve maga a vízesés közelében töltött idő. A floripondio, az ayahuasca (kétkomponensü növényi főzet) és a dohányszertartás. Nekem öt évesen kellett az első floripondio szertartásomon átesni. 8 évesen volt a következő beavatásom az ayahuasca-val, ami azt jelentette, hogy fél litert kellett meginnom a főzetből három napon át. Előtte böjtölni kell, ami nálunk e rítus esetén az étel és az ital teljes megvonását jelenti. Ez egy halál közeli állapotot eredményez. Húsz órán keresztül van ébren ilyenkor az ember egy nap. Ez a folyamat zajlik három napon át, folyamatos víziókkal. A floripondio nagyon erős növény, ezért ez a szertartást csak shuar emberek beavatására szolgál. Ezzel én sem gyógyítok másokat a közösségen kívül.

\section{Mitől félnek, hogy nem osztják meg legszentebb növényüket a flori- pondiot a törzsön kívül senkivel?}

Az új hatalom változást hoz. Emellett a test és az érzelem egyensúlyát követeli meg a szertartás, így veszélyes lehet. Az emberek többsége a városokban nagyon szennyezett, sok a problémájuk, fáradtak szellemileg, rendezetlen a testük a drogok és a rossz élelem miatt. Nem lehet ezeket a növényeket megmutatni felkészülés nélkül, mert káoszt fog hozni a fejükbe. Pszichológiai problémát tud okozni, ha nem tiszta állapotban érkeznek a szertartásra. Ennek következménye az lehet, hogy nem tudnak Arutammal világába lépni, és ha esetleg igen, akkor visszalépni materiális valóságukba. Ezért kell az adaptáció, a ceremónia, a rítus, mert ezektől felkészülnek és kitisztulnak.

\section{Népe hogy használja a gyógyszereket (medicine: ayahuasca, flori- pondio, dohány)?}

Mindig, egész életünkön keresztül. Alapvető része a kultúránknak, lelki, testi és szellemi egészségünknek. Az ősök tudása ez, amit generációról-generációra adtak, adunk át egymásnak. 


\section{Sámánválasztásnál ki dönti el, hogy kiból lesz sámán? A szellemek, a közösség vagy az előző sámán?}

Többféleképpen lehetséges ez. Az egyik, a természetes, egyenes (linar), hogy vérvonal alapján az apa átadja fiának a hagyományt, ha szeretné, hogy a leszármazottja folytassa hivatását. Azonban lehet, hogy valaki eldönti, hogy erre az útra szeretne lépni és akkor keres tanítókat, próbál információkat szerezni. Kérdések fogalmazódnak meg benne és ez az út számára. Azonban ez csak akkor lehetséges, ha meg van a megfelelő attitúdje hozzá. Vannak, akik keresik ezt az utat, de nincs képességük és akaraterejük. Sokan elkezdenek valamit, de nem fejezik be, mert nem tudják belerakni az erőt. Fontos része a sámánizmusnak az út formája, a rituális struktúra, maga a tudás, amit kifejlesztett formában gyakorolsz. Ha ezeket a tudásokat, formákat elsajátította, utána neki tud látni a gyakorlásnak. A hagyomány és a rítusok adottak, az út, ahogyan gyakorlod egyéni, így lesz az ismeret és a szellem dinamikus, elő.

\section{A shuar törzs jelenlegi helyzete és a letelepedés oka:}

Az új irányító rendszerek nagy hatással vannak az életünkre. Ezeket a nehézséget nem csak az ecuadori „rendszertől” kapjuk, hanem a világban általánosan megváltozott a berendezkedés, a gondolkodás és az értékrend.

Nálunk ez azzal kezdődött, hogy elvették az értékeinket és ez azt eredményezte, hogy nekünk shuarok-nak el kellett kezdjünk gondolkodni a pénzen. Jó dolog-e vagy sem, mindezt annak a függvényében, hogy mi a valóság. A régi shuar férfiaknak sok nejük volt, öt-hat és ezektől a feleségektől született tíz gyerekük, mint ahogy nekem is. Mivel nagycsaládra volt szükség ahhoz, hogy elegen legyünk az élelemszerzéshez, vadászathoz és a harchoz. Ez is egy rendszer volt, a természet törvényének rendszere, mert ha nem élsz így, nem tudsz enni, inni, élni. Fel kell ébredni! Ez a természeti törvényekre épülő szokás, már nem szolgálja a mai érdekeket. Ezek a praktikák a változásokkal új élet stratégiára, ismeretre szorulnak. Jelenleg a shuar férfiak soványak, és két-három gyereknél nem vállalnak többet, emiatt már nincs közösség, ahol én is végezhetném munkám. A fiataloknak már nincs igénye a régi praktikák, ismeretek elsajátítására. A shuarok gyengülésének másik oka, hogy vándorló életmódot folytattak, aminek köszönhetően mindig volt élelem. Azonban a vándorlás megállt, mivel nincsen már elég terület, ahol élhetnénk, emiatt mostanra letelepedtünk. Azonban ennek a hátránya az, hogy ha állatokat tartunk, akkor egy idő után nem lesz elegendő növény, ami táplálja az állatokat és a családokat. Emiatt a táplálék kevesebb lesz, az emberek gyengülnek, és úgy döntenek, hogy megváltoztatják a valóságukat. Elmennek a piacra, ahova busszal tudnak eljutni. Tehát már maga, hogy táplálékhoz jusson pénz nélkül megoldhatatlan. Ez hatalmas probléma, az emberek harcolnak egymással, a városok szennyezik a levegót és egymást. 


\section{Dobot használ-e ő vagy a törzsében az ősök? Ha igen, akkor milyet? Ha nem akkor nekik mi a hangszerük, hangszereik, amiket szertar- tásokon használnak.}

Egyik fő rituális hangszerünk a shishin. Bambusz növényt összegyüjtjük és abból egy csokrot formálunk, amit rázni kell, mint egy csörgőt. Rengeteg féle hangszert használunk, mivel ezeknek igen erős gyógyító hatása, ereje van. Legfontosabbak a tuman, ami egy hajlított húr, amin lehet játszani (dorombszerú), illetve a kaeer, ami egy kéthúros hegedú. Dobból kicsi van, azonban a bot (pañan) elengedhetetlen a rituális hangszerek használatakor. Mivel ezzel a bottal éneklünk. A bot a vezetőé, de mindenki használhatja rituális célból.

Miért fontos a gyógyításban az ének?

Az ének kifejezése a legközelebbi a szellemhez. Megvannak az értelmezései és a hagyomány, hogy a különböző égtájak és segítő szellemekhez hogyan és melyik dallal lehet kapcsolódni. A szellemhez a vér, a víz és a lélegzet áll a legközelebb. Így az ének a válasz a lélegzésre, a vibráció, a legművészibb forma, hogy kifejezd az érzéseid. A hang, vibráció, felemeli az erőt, ami mindenkiben benne van.

\section{Hogyan létesít kapcsolatot a szellemekkel? Elmesélne-e egy ilyen ta- lálkozást? Kit/Kiket szólít meg (segítőszellemek)?}

Ez egy rituális forma. Először az ég, majd a föld szellemét, azután a négy égtáj szellemeit hívom. Minden kultúrában a forma más és más. A Fuego Sagrado de Itzachilatlan 7 összeegyezteti az északi és a déli hagyományokban élő rituális kapcsolatteremtést, beleértve ebbe a tüzet, a mennydörgést, a vizet, a szelet. Azokat, akik képesek megszállni az anakondát, a tigrist és az erős növényeket. Ehhez azonban szükség van az uwishin-re, azaz a sámánra. Bármely ember képes lehet kapcsolatba lépni a szellemekkel, csak nem ismerik fel, hogy azok hozzá szólnak, ebben tud segítséget nyújtani a sámán.

\section{Mivel tisztítják rituális tereiket, eszközeiket és magukat?}

Kopallal, cédrussal, salviaval (zsálya), és a Palo santo azaz a szent fa füstölésével. - Ez aromaterápia, amiket szeretnek a szellemek. A füst, ami a növényekből jön, eszenciája a szellemeknek. Ez alkalmas tisztítani a tereket, illetve erősíteni az energiát.

\section{A lélekről mit gondol?}

A fény! Az a legnagyobb mágia, hogy itt vagyunk az életben és létezünk, ezért nem látják az emberek, hogy milyen egyszerú.

Itzachilatlan Szent Tüze 


\section{A szellemról mit gondol?}

A fa meggyullad, mert van energiája, lángokat csinál, és ez a láng a szellem. Az üresség, amit érzel magadban, az az elmeállapotod. A szellem, az elme nagyon erős, képes felépíteni és utána lerombolni önmagát. Az elme a bölcsesség és a másik pillanatban ennek a semmibe vétele is.

\section{A testról mit gondol?}

A test a materiális forma. Megtestesülés. Minden, ami létezik az megvan a természetben. Mi emberek alapvetően föld elemüek vagyunk. Minden, amit megeszünk, újra használódik, osztályozódik. Ez csinálja a vért, és végül ez a vér az élet nektárjává változik, ez tapad össze a sárral, ami mi vagyunk. Az emberek az erő, és ez maga a mágia, amiről misztikaként beszélnek.

El kell érni egy szintű bölcsességet, hogy érdektelen légy bizonyos dolgokkal szemben. Mivel miből áll önmagában az ismeret? Amikor nyugodt vagy az elmédben és békében a szíveddel. Ez az, ami harmonizál. Ahhoz azonban időre és gyakorlatokra van szükség, hogy az elme és a lélek a testtel is harmóniába kerüljön. Azonban elengedhetetlen hozzá, hogy az emberek építsék kapcsolatukat a szellemekkel.

\section{Mit ért a Szellemmel való munkán, spiritualitáson (ő fogalmaz ezzel a szóval), sámánizmuson?}

Ez nem vallás, nem a materiális világ, nem a templom, nem a tollak, nem a dob és nem is az út. Ez ennél mélyebb, maga az élet forrása, hogy megszületik az erő minden formában. Ez annak a belső tudása, hogy hogyan éld az életed. A különböző kultúrák próbálják élni saját kulturális spiritualitásukat. Azonban ez ma nehéz. Az emberek össze vannak zavarodva, nem tudnak figyelni, kavarodás van szellemükben, emiatt nem látják már azokat az értékeket, amiknek gyakorlása az együttesei a tetteknek és a formáknak. Tudatosan kell élni a világban! Nálunk shuaroknál a vízesés minden fiatalnak és idősnek segít felébreszteni ezt az erőt magában, ami tudatossá tesz minket. Azonban, ha olyan területen élsz ahol nincs víz (mert nálunk a vízesés Arutam-nak az első megtestesülése), hogyan vigyázz az életedre? Ezért fontosak a ceremóniák, szertartások, maguk a rítusok. Ezek a rítusok rejtik magukban és segítik előhívni a tudást, az ismeretet, a bölcsességet. Ha ezt észreveszed, akkor elkezdesz e tudás szerint cselekedni és ez a spiritualitás. A nehézséget jelenleg az jelenti, hogy ezeket az ősi tudásokat nagy erók szennyezik, és ezek az erók elnyelik az embereket. Mivel olyan életmódot élnek, amiben nincs idő, hogy ezekre fókuszálják energiáikat. Ezért találták ki a vallást. Istenről kezdenek el beszélni és ezzel adnak egy formát ezeknek az erőknek, ami számukra a probléma megoldását jelenti... Ezek a rendszerek. Látnunk kell a valóságot és az értékeinket, azonban ezt gyakorlattá kell tenni és abba az életbe integrálni, amit élünk, ami a közegünk. A shuarok már nem élnek eredeti módon területeiken. Nekik is tudatosnak kell lenniük és al- 
kalmazkodni környezetükhöz és a változásokhoz. Látniuk kell, hogy nem jó, ha öt gyereke van egy embernek, mert vízre és élelemre van szükség az élethez. Ezeket a változásokat fel kell ismerni, különben gond lesz. Azonban mindeközben is dolgozni kell spirituális fejlődésükön, még ha nehéz is, mivel a jelenlegi életformájuk elviszi őket ettől a kapcsolattól.

\section{Mit jelent a vízió? Mikor? Hogyan írná le?}

Két megértésem van a révülésról, vízióról. Az egyik, amit a vízió szóval írunk le. Személyesen a vízióról azt gondolom, hogy akik azt mondják, hogy vannak, azoknak igazából nincsenek is. Mivel az ego az, ami elképzeli, ami keresi azt, hogy legyen víziója. Ez az ember csapdája. Rengeteg megtestesülése van az egónak. Ez az önbecsapás, mert ha lennének víziók, vagy nem szokványos gondolatok, akkor nagy fontosságot tulajdonítanának neki, hogy mennyire érdekesek. Mert nincs jelen az életükben, mert ha itt lenne és tudjuk, akkor hát mire szolgálna a vízió. Ez az emberi ego, ami ragaszkodik valamihez. Az elme erős, azonban tud pozitív és negatív is lenni. Ha vízióról beszélünk egy kicsit más fogalmat értve alatta, akkor két formát különíthetünk el. Az egyik a rendezettség, bölcs, kiegyensúlyozott ismeretekkel rendelkező mentális, testi és lelki állapot, ami megértéseket teremt. A fejed befogadja, ami éppen történik, és így az elméd kommunikál a lélekkel és a testtel. Ez a pillanat a vízió: rendezett formája a tudásnak, hogy megértsd, hogy tudsz sikeres lenni az életben. Mi az élet sikere? A konkrétan itt létező lehetőségek, a harmóniád. Megértsd a fényt, mert erről a fényről beszélünk. Hogy ezt melyik és milyen úton teszed, nem számít, a lényeg a megértés. A másik vízió abból adódhat, hogy leszármazottjai vagyunk a „fenti” erőknek, mint például a víz leszármazottjai, amik Arutam megtestesülései. Ezek az erők végtelenek, meghaladják az emberi képzelő erőt és bele avatkoznak életünkbe. Felkészült az ember, hogy kapcsolódjon ezekkel az erőkkel és megtapasztalja, hogy értse ezeket a vízióit. A shuarok megtalálták a kommunikáció útját, ez az a vízió, ami a révüléssel függ össze. Alapvetően akkor van bennünk ez a kommunikációs út, amikor megszületünk, és amíg anyánk táplál minket, és amikor meghalunk, mert ezek más tudatállapotok, mint amit normál életünkben élünk. Az emberek többségének ez az a két lehetőség, amikor ez az út ismert. Mikor anyukánk táplál, akkor azért, mert rajta keresztül létezünk. Az izzasztókunyhó ezért van, mert az anya méhe átadja újra a tudást és ismét végig visz a születés útján. Ezért hasznos az izzasztókunyhó, mert itt sok mindent meg tudnak oldani az emberek. Amikor meghalunk, ugyanígy kinyílik ez a lehetőség, hogy ebben a formában legyünk és erőben.

\section{Hova kerülünk a halál után? Mi is az a halál?}

Vannak dolgok, amiket nem baj, ha nem tudunk, majd úgy is megtudjuk, mikor meghalunk. Azonban nekem van egy érzésem, hogy mit jelent a halál. Egy olyan munka, amit nem tudtál megismerni. A halál egy olyan erő, ami nem enged 
békén élni itt. A boldogságot nehezíti a halál, mert kíváncsivá tesz és bizonytalanná, amiatt, hogy tudni akarod mi a jövő. Azonban a halál a jövő titka a létezőknek. Érezzük magunkban a bizonytalanságot, aggódunk, hogy mi lesz halálunk után. Félünk, ezek azok az érzések, amik elveszik a jelen életed békéjének lehetőségét. Nyugodtnak kell lenni. Ki jött vissza? Lesz valaki, aki tudja a halál titkát? Ha valaki felfedezi, akkor elmegyünk és megkeressük, az lesz az ember győzelme!

Kereszténységről mi a tapasztalata?

Ebben a szóban van egy erő, ami a félelembe van ültetve. Ez az, amit én problémának látok. Az emberek többsége félelemben éli az életét ahelyett, hogy szabad, saját utat járna, ami erősítené és biztonságot adna a számára. Egy olyan vezetőt helyeznek maguk fölé, akitől félniük kell, hogy megbünteti-e őket vagy sem. Úgy nem lehet spirituálisan fejlődni, hogy közben félünk valaki ítéletétől. Azonban, ha ezt átgondoljuk, azt láthatjuk, hogy ez egy politikai rendszer. Ördög és Isten a két legnagyobb politikus, amit az ember teremtett. Itt kell ebben a világban szabadnak lennünk és nem készülni a mennyország nyugalmára, hanem itt megteremteni, és ezt magunkban kell keresnünk, megtalálnunk.

\section{Vannak-e a törzsben, akik keresztények?}

Mindenki. Ez állami törvény. Latin-Amerikában ez kötelező. Nincs vallásszabadság. Azt a tudást is meg kell tapasztalni, hogy mi nem szeretnél lenni.

\section{Mit akar adni a világnak? Miben érzi hívatását?}

Felelősség. Az az ember, aki birtokolja a tudást, annak az az első, hogy ezt megossza. Ez egy szolgálat. Mi a tudás? Egy eszköz, és mire szolgálnak az eszközök? Hogy dolgozzunk velük és kezdjünk velük valamit. Számomra ez a gyógyítás. Azonban ez a hivatás több mint egy feladat. Ez munka, elkötelezettség a saját magam és más életéért. Számomra ez a megértés. Ha én tudok dolgokat és ettől jól vagyok, akkor mindenkinek jól kell lennie körülöttem.

\section{Mit akar, mit tud adni, mint sámán lakhelyén, ill. Európának?}

Ahogy mondtam, ez egy munka, ezért kötelességem, hogy így éljek és dolgozzak, hogy ezeket a tudásokat mindenhol használjam, ahol élek. A sámánizmus egy út, amit mindennap járni kell. Az ének, imák, légzés eszközök ennek gyakorlására. Ezeket meg kell élni. Mindez mire szolgál? Arra, hogy jól legyünk, hogy egészségesek legyünk, mert amikor erőd van, tudsz dolgozni. Sikered van, és ha sikeres vagy, akkor boldog vagy. Egyszerű a válasz, az egészséges emberek megygyógyítanak másokat. 


\section{Mit lát: mit ad ez az európaiaknak?}

Az európaiak számára ez a növények rituális megtapasztalása. Ez egy évezredes munka. Egy tevékenység, ami felébreszti a tudatosságot. A növények segítenek, hogy az emberek felébresszék magukat és megláthassák saját világukat. Látom a szükségletét, hogy mi kell az európai ember gyógyulásához. Ez egy fajta magatartás, amiben egy idő után észreveszik, hogy körülöttük nem minden aktivitás jó. Ezután elkezdik keresni, hogy hogyan lehetne jó, és újra tudatában lesznek annak, hogy mi a jó és mi a nem. Ez a magatartás engedi, hogy növekedjenek és érettek legyenek. Amikor valaki vállalja ezeket a megértéseket, elkezd felelősséget vállalni a saját életéért. Ez a praktika, és amit ebből származik, az a spiritualitás.

\section{IRODALOMJEGYZÉK}

Adelaar, W.F.H. (2004). The languages of the Andes. Cambridge: Cambridge University Press.

Bennett, BC. (1992). Hallucinogenic plants of the Shuar and related indigenous groups in Amazonian Ecuador and Peru. Brittonia, 1992/4/4, 483-493.

Bitsch, J. (1968). Jivaro indiánok. Budapest: Táncsics.

Boglár L. (2010). A sámán nyaklánca. Budapest: Nyitott Könyvmúhely.

Bokor P., Frecska E., Csányi B., \& Brys Z. (2012). Az ayahuasca terápiás lehetőségei és veszélyei. LAM, 22, 08-09.

Calabrese, D.J. (2013). A Different Medicine:Postcolonial Healing in the Native American Church. Oxford: Oxford Ritual Studies.

DeKorne, J. (1997). Pszichedelikus sámánizmus. (J. Melocco \& Nagy M., Ford.). Budapest: Ursa Maior. (Eredeti: Psychedelic Shamanis The Cultivation, Preparation, and Shamanic Use of Psychotropic Plants)

Eliade, M. (2005). A sámánizmus. (Saly M., Ford.). Budapest: Osiris. (Eredeti: Shamanism: Archaic Techniques of Ecstasy)

Frecska E. (2008). „Ayahuasca Versus Violence : a Case Report.”Neuropsychopharmacologia Hungarica,18 (2), 103-106.

Frecska E., Csökli Z., Nagy A., \& Kulcsár Z. (2004). „Neurophenomenological Analysis of the Therapeutic Relationship in Ritual Healing." Neuropsychopharmacologia Hungarica, 6 (3), 133-143.

Frecska E.,Móré C.E.,Vargha A., \& Luna, L.(2012). „Enchancement of Creative Expression and Entoptic Phenomena as After-Effects of Repeated Ayahuasca Ceremonies." Journal of Psychoactive Drugs, 44 (3),191-199.

Gennep, A van. (2007). Átmeneti rítusok. (Vargyas Z., Ford.). Budapest: L'Harmattan. (Eredeti: The Rites of Passage)

Luna, L. (1984). The Concept of Plants as Teachers Among Four Mestizo Shamans of Iquitos, Northeastern Peru. The Journal of Ethnopharmacology,11 (2), 135-56.

Ortutay Gy. (Szerk.). (1977-1982). Magyar néprajzi lexikon. Budapest : Akadémiai Kiadó 
Pellizzaro, S. (1978). Mundo Shuar 3.: El Uwishin. Ecuador: Centro de Documentación, Investigación y Publicaciones SUCUA (Morona Santiago).

Perruchon, M. (2003). I am Tsunki : Gender and shamanism among the Shuar of Western Amazonia. Uppsala: Acta Universitatis Upsaliensis.

Rubenstein, S. (2002). Alejandro Tsakimp: A Shuar Healer in the Margins of History. Nebraska: University of Nebraska.

Strassman, R. (2001). DMT: The spirit molecule. Rochester-Vermont: Park Street Press.

Szummer Cs. (2011). „A pszichedelikus élmény pszichológiai megközelítései: James, Maslow és a transzperszonális pszichológia (I. rész).” Lege Artis Medicinæ, 21 (5), 404-408.

Szummer Cs.(2012a). „A pszichedelikumokban rejlő veszélyek és lehetőségek (III. rész).” Lege Artis Medicinæ, 22 (5), 395-397.

Szummer Cs.(2012b). „Pszichedelikumok és kvázi-misztikus élmények (II. rész).” Lege Artis Medicinæ, 22 (2), 78-80.

Szummer Cs. (2015). „A pszichedelikus élmény, mint a fenomenológiai kutatás eszköze a filozófiában és a pszichológiában”. Magyar Filozófiai Szemle. 4, 136-150.

Szummer Cs. (2015). Pszichedelikumok és spiritualitás. Budapest:. L’Harmattan.

Turner, V. (2002). A rituális folyamat. (Orosz I., Ford.). Budapest: Osiris. (Eredeti: The ritual process)

Wallis, R.J. (2003). Shamans and neo-shamans. New York: Routledge. 